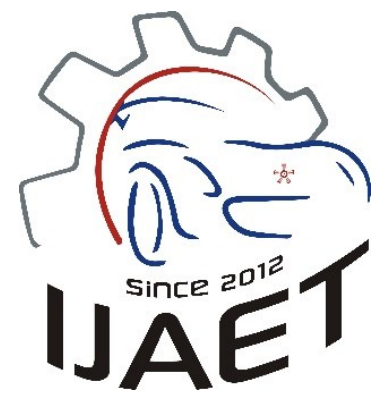

e-ISSN: 2146 - 9067

International Journal of Automotive

Engineering and Technologies

journal homepage: http:// http://dergipark.gov.tr/ijaet

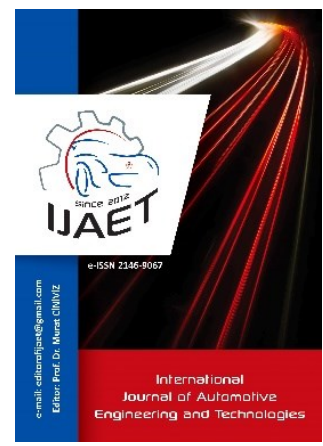

Original Research Article

\title{
A Comparative study of engine performance and exhaust emissions of biodiesel and its blends produced from waste cooking oil and neutralized waste cooking oil
}

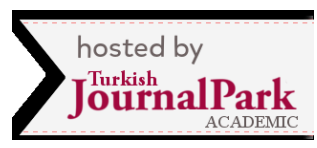

\author{
Ali Koray Özgün1, Tanzer Eryılmaz ${ }^{2 *}$ \\ ${ }^{1}$ Ankara University, Vocational School of Health Services, Department of Orthopedic Prosthesis and Orthosis, \\ Ankara/TURKEY \\ ${ }^{2}$ Bozok University, Faculty of Engineering and Architecture, Department of Biosystems Engineering, \\ Yozgat/TURKEY
}

\author{
ARTICLE INFO \\ * Corresponding author \\ tanzer.eryilmaz@bozok.edu.tr \\ Received: April 01, 2018 \\ Accepted: July 12, 2018 \\ Published by Editorial Board \\ Members of IJAET \\ (C) This article is distributed by \\ Turk Journal Park System \\ under the CC 4.0 terms and \\ conditions.
}

\begin{abstract}
In this present study, the neutralization process was applied in waste cooking oil (WCO), and neutralized waste cooking oil (NWCO) was derived and the physical properties of $\mathrm{WCO}$ and NWCO were designated. Waste cooking oil biodiesel (WCOB) and neutralized waste cooking oil biodiesel (NWCOB) were produced from these oils by using the transesterification method. The acquired biodiesels were blended with Euro Diesel (ED) volumetrically in the rates of $20 \%$ and $2 \%$ and fuels in the forms of $\mathrm{B} 20(20 \% \mathrm{WCOB}+80 \% \mathrm{ED})$, $\mathrm{B} 2(2 \% \mathrm{WCOB}+98 \% \mathrm{ED}), \mathrm{B} 20 \mathrm{~N}(20 \% \mathrm{NWCOB}+80 \% \mathrm{ED})$ and $\mathrm{B} 2_{\mathrm{N}}(2 \%$ $\mathrm{NWCOB}+98 \% \mathrm{ED})$ were derived and the properties of all of these fuels were designated. The derived fuels were tested in a single cylinder diesel engine and compared with ED and them torques, powers, specific fuel consumptions, $\mathrm{CO}$, $\mathrm{CO}_{2}, \mathrm{HC}, \mathrm{NO}$ and smoke intensities were investigated. In conclusion, by comparing the engine performance of NWCOB and WCOB, it was found that the maximum torque, maximum power and minimum specific fuel consumption values increased in the rates of $1.81,2.64$ and $6.47 \%$, respectively. By comparing their exhaust emissions, it was found that the biodiesel fuels were more environmental friendly in comparison to the diesel fuels and their $\mathrm{CO}, \mathrm{HC}$ and smoke intensity were lower, and their $\mathrm{NO}$ and $\mathrm{CO}_{2}$ emissions were somewhat higher. When the neutralization process was applied to WCO, its emission values improved and this illustrated that NWCOB was more environmental friendly in comparison to WCOB.

Keywords: Biodiesel, Waste cooking oil, Transesterification, Neutralization, Fuel properties.
\end{abstract}

\section{Introduction}

Energy consumption researches gradually in the world due to increased population and unlimited human needs. Climbing energy prices impact substantially the industry, agriculture, service sectors and at the same time end-consumers situated at the final link of the chain. Especially climbing oil prices pressurize countries and the countries which do not want to experience energy problems attempt to minimize their oil 
dependency [1]. Since fossil-based resources diminish gradually and due to their effects on the environment, alternative energy sources are at the agenda. One of these energy sources is biodiesel which can be used in internal combustion engines as an alternative to diesel fuels $[2,3]$.

Biodiesel resembles diesel fuels in terms of its physical and chemical properties. Biodiesel is used in diesel engines in its pure form and it can also be used as blended with diesel fuels. Pure biodiesel and biodiesel-diesel fuel blends can be used in engines without a need for modification or by making small modifications. Pure biodiesel is called B100 and a blend of $20 \%$ biodiesel and $80 \%$ diesel fuel is called B20 [4]. Diesel engines are used extensively in agriculture and industry. These engines are preferred owing to their low specific fuel consumption and low exhaust emissions. Researchers conduct studies that could affect the characteristics of alternative fuels that can be used in diesel engines and engine performance. Moreover, Euro lowers the exhaust emission standards gradually and this stimulates day by day the interest on biofuels that can be used in diesel engines without making detailed modifications $[5,6]$.

Biodiesel has lower CO, HC and PM emissions in comparison to the diesel fuel and is a nontoxic fuel produced from vegetable oils and animal fats and can be disintegrated in the nature biologically. Biodiesel does not consist of sulphur and therefore it is more environmental friendly. Sulphur combines with the moisture in the air and leads to acid rain. Moreover, pour and freezing points of biodiesels are significant for the engines to operate at low temperatures. Biodiesel fuel has a higher pour point and cloud point in comparison to diesel fuel. Therefore, problems are experienced during biodiesel fuel use in cold weather conditions. Furthermore, the viscosity and density values of biodiesel fuel are higher than those of diesel fuel. High viscosity and density values lead to problems in the engine fuel injection system. The advantages of biodiesel fuel are its specific fuel consumption, power and torque values similar to diesel fuel [7, 8].

Produced biodiesel from waste cooking oil in their study and tested it in a diesel engine vehicle at TOFAŞ automotive plant and reported that biodiesel usage caused $2.03 \%$ brake power fading and $3.35 \%$ reduction in torque in comparison to diesel fuel. They reported that there were reductions in $\mathrm{CO}$, unburned $\mathrm{HC}$ and $\mathrm{PM}$ emissions in comparison to diesel fuel in the rates of $8.59,30.66$ and $63.33 \%$, respectively, and $\mathrm{CO}_{2}$ emission increased $2.62 \%$ and $\mathrm{NO}_{\mathrm{x}}$ emissions increased $5.03 \%$ as uncovered by the emission tests. They reported that biodiesel consumed $2.43 \%$ more fuel in comparison to diesel fuel [9].

Performed full load tests on the fuel produced and derived from corn oil in a single cylinder diesel engine at $1800 \mathrm{1} / \mathrm{min}$ to $3200 \mathrm{1} / \mathrm{min}$. They measured engine performance and emission values and compared them with those of the diesel fuel. They found $7.5 \%$ reduction in engine torque, $5.7 \%$ reduction in power and $9.24 \%$ reduction in specific fuel consumption. By using corn oil biodiesel, they found $51.4 \%$ reduction in $\mathrm{CO}$ emission and $64 \%$ reduction in light absorption coefficients and 25.31\% increase in $\mathrm{NO}_{\mathrm{x}}$ emission. There was no $\mathrm{SO}_{\mathrm{x}}$ emission found [10].

Produced biodiesel from WCO in their study and prepared blends by using diesel fuel in the rates of 25,50 and $80 \%$ volumetrically and tested them in a diesel engine. They reported that their engine torque and effective engine power were somewhat lower than those of diesel fuel and their fuel consumptions were higher. They found in the emission tests that the $\mathrm{NO}_{\mathrm{x}}$ and $\mathrm{O}_{2}$ values of the methyl ester blends were higher than those of diesel fuel, and the $\mathrm{HC}, \mathrm{CO}_{2}$ and $\mathrm{CO}$ emission values of the methyl ester blends were at lower levels [11].

Studied the environmental effects of biodiesel which is an alternative fuel technology improving agricultural development and reducing foreign dependency of a country. They reported that biodiesel could be produced from waste vegetable oils and animal fats as well and it wasan indispensable opportunity to benefit from waste oils generated in agricultural rural areas and tourism regions. They reported that the environmental risks were reduced by using waste vegetable oils and animal fats for biodiesel production, and an environmental friendly fuel could be derived with lower emission values in comparison to diesel fuel, and biodiesel has a strategic significance and improved the development of agriculture, 
reduced dependency of the countries to foreign resources and is more appropriate environmentally [12].

Produced biodiesel in their study by applying the neutralization process to WCO and with the transesterification method and blended the biodiesel with diesel fuel volumetrically in the rate of $10 \%$. They tested B10 fuel and diesel fuel in a single cylinder, four-stroke diesel engine with direct injection at maximum torque cycle $(22001 / \mathrm{min})$ and at various engine loads (3.75, $7.5,11.25,15$ and $18.75 \mathrm{Nm})$. They analyzed the cylinder pressure, heat release, ignition delay, combustion duration and $\mathrm{CO}, \mathrm{CO}_{2}, \mathrm{NO}_{\mathrm{x}}$ and smoke emissions changes. By comparing B10 and diesel fuel, they saw that when the engine load increased, $\mathrm{CO}$ and smoke emission went down 28.21 and $11.77 \%$, respectively [13].

In this study, biodiesels were produced from WCO and the oil that was produced after the neutralization process was applied to this oil with the transesterification method. These biodiesels were blended with ED fuel volumetrically in the rates of $20 \%$ and $2 \%$. $\mathrm{B} 100, \mathrm{~B} 100_{\mathrm{N}}, \mathrm{B} 20, \mathrm{~B} 20_{\mathrm{N}}, \mathrm{B} 2$ and $\mathrm{B} 2{ }_{\mathrm{N}}$ and $\mathrm{ED}$ fuel that was used as a reference were tested in a single cylinder diesel engine and their torque, power, specific fuel consumption, $\mathrm{CO}, \mathrm{CO}_{2}$, $\mathrm{HC}, \mathrm{NO}$ and smoke values were comparatively analyzed.

\section{MATERIAL and METHODS 2.1. Materials}

WCO used in this study were acquired from collected oils by a private company. In this study, ED was procured from a local petrol station. The technical properties of the engine are shown in Table 1.

Table 1. The Technical Properties of Antor 3LD510 Brand Diesel Engine Used in the Tests

\begin{tabular}{ll}
\hline Technical Properties & \\
\hline Model and Type & Antor 3 LD 510 \\
Cylinder Number & 1 \\
Cylinder Volume & $510 \mathrm{~cm}^{3}$ \\
Cylinder Bore & $85 \mathrm{~mm}$ \\
Stroke & $90 \mathrm{~mm}$ \\
Compression Ratio & $17.5: 1$ \\
Engine Speed & $30001 / \mathrm{min}$ \\
Engine Power & $12 \mathrm{HP}$ \\
Maximum Torque & $3.35 \mathrm{~kW} 18001 / \mathrm{min}$ \\
Specific Fuel Consumption & $190 \mathrm{~g} / \mathrm{HPh}$ \\
Cooling Type & Water Cooled \\
\hline
\end{tabular}

Table 2. The Technical Properties of the Exhaust Emission Device

\begin{tabular}{lcc}
\hline \multicolumn{1}{c}{ Emissions } & Range & Accuracy \\
\hline $\mathrm{CO}_{2}, \%$ & $0-18$ & 0.01 \\
$\mathrm{CO}, \%$ & $0-10$ & 0.001 \\
$\mathrm{HC}, \mathrm{ppm}$ & $0-9999$ & 1 \\
$\mathrm{NO}, \mathrm{ppm}$ & $0-5000$ & 1 \\
Smoke, $\%$ & $0-100$ & 0.1 \\
\hline
\end{tabular}

A Net Fren NF150 brand hydraulic dynamometer was used in the engine tests for exhibiting engine performance. The dynamometer cycle measurement range was 0 $6500 \mathrm{1} / \mathrm{min}$ and the torque measurement range was $0-450 \mathrm{Nm}$. The values during the engine loading were read by using a CAS brand SBA 200L model load cell which could make measurements at the range of $0-200 \mathrm{~kg}$ with $1 \mathrm{~g}$ of precision. The fuel consumption was read with a $2.5 \mathrm{~L}$ capacity fuel tank by CAS brand
BCL-1L model by a Load Cell with a $0-3 \mathrm{~kg}$ measurement capacity with a precision of 0.01 g. Bosch brand BEA 350 model emission measurement device was used for exhibiting exhaust emission measurements, and Bosch brand RTM 430 model smoke measurement kit was used for smoke emission measurements. The technical properties of the exhaust emission measurement device are shown in Table 2.

Methanol that was used in the study for deriving biodiesel from WCO and NWCO was Merck 
brand. Merck brand sodium hydroxide $(\mathrm{NaOH})$ was used as a catalyst with a purity value of greater than $97 \%$ for biodiesel production. Koray Chemical brand phosphoric acid $\left(\mathrm{H}_{3} \mathrm{PO}_{4}\right)$ with a purity value of greater than $85 \%$ was used in the neutralization process. Grade F 160 bleaching earth manufactured by Mohen Company was used in the process of precipitation of undesired particles within oils. The devices shown in Table 3 were used for measuring the physical and chemical properties of fuels.

Table 3. The Technical Properties of the Devices Used in the Tests

\begin{tabular}{lccc}
\hline Device & Model & Range & Accuracy \\
\hline Kem Kyoto & DA-645 & $0.000000-3.00000 \mathrm{~g} / \mathrm{cm}^{3}$ & $\pm 0.00005 \mathrm{~g} / \mathrm{cm}^{3}$ \\
Polyscience & $7306 \mathrm{~A} 12 \mathrm{E}$ & $5-150^{\circ} \mathrm{C}$ & $\pm 0.05^{\circ} \mathrm{C}$ \\
Rapid Tester & RT-1 & $-30-300^{\circ} \mathrm{C}$ & $1{ }^{\circ} \mathrm{C}$ \\
Kem Kyoto Electronics & MKC-520 & $0.001-100 \mathrm{mg}$ & $0.001 \mathrm{mg}$ \\
IKA & $\mathrm{C} 200$ & $0-4000 \mathrm{Joule}$ & $1 \mathrm{~J}$ \\
IKA & T25 & $240001 / \mathrm{min}$ & $501 / \mathrm{min}$ \\
Denver Instrument & TP-214 & $210 \mathrm{~g}$ & $0.1 \mathrm{mg}$ \\
IKA & $\mathrm{C}-\mathrm{MAG} \mathrm{HS7}$ & $100-1500 \mathrm{~d} / \mathrm{d}$ & $1001 / \mathrm{min}$ \\
Elektro-mag & M6040P & $0-300^{\circ} \mathrm{C}$ & $1{ }^{\circ} \mathrm{C}$ \\
HiTRAX RUN & - & $0-40 \mathrm{~min}$ & $0.01 \mathrm{~s}$ \\
Hanna Checktemp & & $(-50)-150^{\circ} \mathrm{C}$ & $0.1^{\circ} \mathrm{C}$ \\
\hline
\end{tabular}

\subsection{Methods}

WCO was refined from substances such as waste cooking particles by physical refining. WCO was heated to $100^{\circ} \mathrm{C}$ in a magnetic mixer with a temperature controlled heater and kept at this temperature for $2 \mathrm{~h}$ and the excess water generated during use was removed.

These oils were kept until their temperature dropped to $85^{\circ} \mathrm{C}$ after the process of water removal from WCO. The mixer was operated by maintaining this temperature as constant and phosphoric acid was added at the rate of $0.2 \%$ of the total oil for the neutralization process and blended for $10 \mathrm{~min}$. As the mixing process continued, $1 / 3$ rate of $\mathrm{NaOH} /$ distilled water mix at the rate of $5 \%$ of oils was sent to $\mathrm{WCO}$ and blended for 5 more min. Subsequently, the mixer was turned off and let stand for $3 \mathrm{~h}$ for the precipitation of phosphorous compounds and these compounds were removed from the oil. WCO was reheated to $85^{\circ} \mathrm{C}$ and $20 \%$ of oil at the same temperature was washed with water. It was let stand for $3 \mathrm{~h}$ for waste water to settle and then waste water was removed. The drying process was performed at $100^{\circ} \mathrm{C}$ for $2 \mathrm{~h}$ to remove excess water in WCO. It was let until the temperature of WCO dropped to $85^{\circ} \mathrm{C}$ and the mixer was operated and bleaching earth was added at the rate of $2 \%$ of oil and it was blended for $45 \mathrm{~min}$. Subsequently, the mixer was turned off and it was let for $3 \mathrm{~h}$ for bleaching earth to precipitate and the precipitated bleaching earth was removed. After the neutralization process, WCO was filtered [13, 14, 15].

In order to produce biodiesel from $\mathrm{WCO}$ and NWCO, methanol as much as $25 \%$ of oil and 3.5 $\mathrm{g}$ of $\mathrm{NaOH}$ for each liter of oil was dissolved in a magnetic mixer and methoxide was derived. This methoxide was added to the oil blended at $55^{\circ} \mathrm{C}$. The revolution of the mixer was adjusted to $1000 \mathrm{l} / \mathrm{min}$ during the mixing process and the blend was blended for $60 \mathrm{~min}$ and then the mixer and heater were stopped. The blend was let for $180 \mathrm{~min}$ for the glycerol remaining in the biodiesel to precipitate and the glycerol was removed. Crude biodiesel was heated to $75^{\circ} \mathrm{C}$ and methanol was removed. It was let for $15 \mathrm{~h}$ for the glycerol to precipitate and at the end of $15 \mathrm{~h}$, the glycerol was removed. Meanwhile $\mathrm{pH}$ value of the biodiesel was measured and it was washed until it became neutralized with distilled water because the reaction was basic. The purpose of washing was to remove alcohol that remained in the biodiesel and did not react, the remaining fatty acids, $\mathrm{Na}+$ and $\mathrm{K}+$ ions, catalyzers and glycerol that was possible to remain during elution. The washing process was performed as the biodiesel temperature was $50^{\circ} \mathrm{C}$ and the distilled water's temperature was $50^{\circ} \mathrm{C}$. It was let for $12 \mathrm{~h}$ for the water to settle and then the settled water was removed by using a separation funnel. This biodiesel was taken to a magnetic mixer with a heater and heated to $120^{\circ} \mathrm{C}$ above the water boiling point. The biodiesel was dried at $120^{\circ} \mathrm{C}$ for $2 \mathrm{~h}$. This way, 
biodiesels were produced from WCO and NWCO.

\subsection{Preparation of $B 2, B 20$ and $B 2{ }_{N}$, B20NFuel Blends}

WCOB, NWCOB and ED were blended volumetrically in the rates of $2 \%$ and $20 \%$. During the blending process, first $98 \%$ and $80 \%$ ED were placed and then $2 \%$ and $20 \%$ biodiesels were added on top sufficient to derive the blend. The blending process was first performed by using a laboratory type IKA ULTRA-TURRAX brand T25 model mixer at $1500 \mathrm{l} / \mathrm{min}$ for $7.5 \mathrm{~min}$ and then by using a Velp Scientifica brand DLS F20100155 model homogenizer at $24000 \mathrm{1} / \mathrm{min}$ for $7.5 \mathrm{~min}$ in other words for a total of $15 \mathrm{~min}$ and the blend was homogenized. Hence, B2, B20 and B2, B20 fuel blends were derived [16]. The fuel analyses results are shown in Table 4.

Table 4. The Analyses Results of Waste Cooking Oil, Neutralized Waste Cooking Oil, B100, B100N, B20, B20N, B2, $\mathrm{B} 2_{\mathrm{N}}$ and ED Fuels

\begin{tabular}{|c|c|c|c|c|c|}
\hline Property & $\begin{array}{l}\text { Density } \\
\left(\mathrm{g} / \mathrm{cm}^{3}\right)\end{array}$ & $\begin{array}{l}\text { Kinematic viscosity } 40^{\circ} \mathrm{C} \\
\left(\mathrm{mm}^{2} / \mathrm{s}\right)\end{array}$ & $\begin{array}{l}\text { Flash point } \\
\left({ }^{\circ} \mathrm{C}\right)\end{array}$ & $\begin{array}{ll}\text { Water } & \text { content } \\
(\mathrm{mg} / \mathrm{kg}) & \end{array}$ & $\begin{array}{l}\text { Calorific } \\
(\mathrm{MJ} / \mathrm{kg})\end{array}$ \\
\hline ED & 819.47 & 2.624 & 59 & 24.773 & 47.445 \\
\hline WCO & 921.74 & 32.760 & 231 & 579.78 & 39.813 \\
\hline WCOB & 886.30 & 4.906 & 174 & 577.60 & 40.740 \\
\hline B20 & 829.73 & 2.973 & 66 & 238.45 & 45.888 \\
\hline B2 & 820.23 & 2.689 & 60 & 41.055 & 46.887 \\
\hline NWCO & 922.55 & 32.877 & 225 & 562.69 & 39.923 \\
\hline NWCOB & 887.84 & 5.201 & 167 & 735.85 & 40.946 \\
\hline $\mathrm{B} 20_{\mathrm{N}}$ & 832.57 & 3.027 & 65 & 188.51 & 46.202 \\
\hline $\mathrm{B} 2{ }_{\mathrm{N}}$ & 821.18 & 2.779 & 60 & 51.207 & 47.152 \\
\hline
\end{tabular}

\subsection{Engine Performance Tests}

These tests were performed to study the effects of the produced WCOB, NWCOB, B2, B20, $\mathrm{B} 2 \mathrm{~N}$ and $\mathrm{B} 20_{\mathrm{N}}$ fuels on engine performance and their environmental effects. The tests were performed by using an engine test apparatus set up in Aksaray University, Technical Sciences Vocational High School, Automotive Program, Automotive Laboratory.

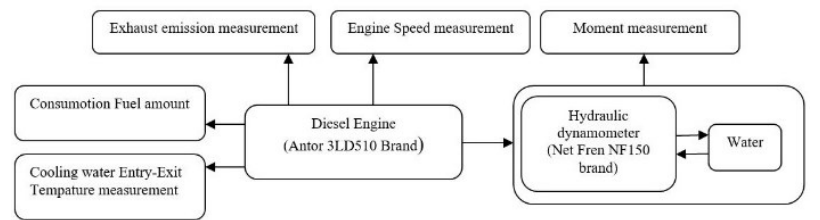

Figure 1. The Scheme of the Test Apparatus Used for the Engine Tests

The engine tests were performed in accord with the TS 1231. In this test method, engines selected from the serial production are tested along with their auxiliary parts (water pump, ventilating fan, generator, suction and exhaust equipment). The measurements are made under $99 \mathrm{kPa}$ dry air pressure, at $25^{\circ} \mathrm{C}$ and $60 \%$ relative air humidity [13-14]. The test apparatus consisted of a hydraulic dynamometer, engine, exhaust emission device and the units feeding and controlling them. The test connection scheme is shown in Figure 1.

Before the engine was operated by using B2, $\mathrm{B} 20, \mathrm{~B} 100$ and $\mathrm{B} 2 \mathrm{~N}, \mathrm{~B} 20_{\mathrm{N}}, \mathrm{B} 100_{\mathrm{N}}$ fuels, it was loaded for both checking the connection setup and test apparatus and also for the engine to start the regime, and it was operated by using ED for 10-12 min. ED was tested as a reference fuel, the engine was loaded and the values were received. Subsequently, B2, B20, B100 and B2 ${ }_{N}, B 20_{N}$, B100 fuels were tested.

Before each test, the engine was operated, loaded and entered into regime. The engine was loaded by using a hydraulic dynamometer as the engine was in full gas position. The measurements were made after the engine reached the operation temperature during the tests. The engine was loaded when the engine was in full gas position and the engine speed was reduced in hundreds. The speed was adjusted after the engine was loaded and it was read on the indicator at each round and recorded. During the experimental studies, the parameter of $\lambda$ (lambda) was kept constant at 1. The fuel consumption and exhaust emission values were measured by using a fuel meter working based 
on the principle of the same round and load. The atmospheric conditions were determined during the tests. The fuel entry temperatures were measured as $20^{\circ} \mathrm{C}$ and the environmental temperature was measured as $25^{\circ} \mathrm{C}$ and the engine cooling water exit temperature was kept constant at $70^{\circ} \mathrm{C}( \pm 5)$. The exhaust gas was released to the outer environment. The exhaust emission measurements were made at full load and each round. For uncovering the fuel properties, the power, torque, specific fuel consumption values were analyzed as a function of the engine speed when the engine was at full gas position.

\section{RESULTS AND DISCUSSION}

\subsection{The Properties of the Fuels Used in the Tests}

Comparing $\mathrm{WCOB}$ and $\mathrm{NWCOB}$ properties with EN 14214, B20, B2, B20 ${ }_{N}$ and B2 $2_{N}$ fuel blend properties and diesel fuel properties in accord to the EN 590; it was found that the water content of WCOB and B20 fuels did not comply with the kinematic viscosity and water content standards of the NWCOB. The properties of the other fuel blends other than B20 were within the limit values.

\subsection{The Engine Performance Test Results}

The engine tests were performed by using ED, WCOB, NWCOB and fuel blends and the changes in the engine torque, one of the engine properties, depending on the engine speed are shown in Figure 2. As a result of the engine tests, the speed values at full load and at each round range of WCOB (3100 and $32001 / \mathrm{min}$ respectively, with 23.347 and $35.116 \%$ reduction) and all of the speed values of $\mathrm{B} 2$ and B20 fuel blends were lower than those of ED fuel. The other speed values of the NWCOB (at 3100 and $32001 / \mathrm{min}$, there was reduction of respectively 18.261 and $29.159 \%$ ) and all speed values of $\mathrm{B} 2 \mathrm{~N}$ and $\mathrm{B} 20_{\mathrm{N}}$ fuel blends were lower than those of ED fuel. Maximum engine torque was achieved at $14001 / \mathrm{min}$ when $\mathrm{ED}, \mathrm{B} 100_{\mathrm{N}}$, $\mathrm{B} 20, \mathrm{~B} 20_{\mathrm{N}}, \mathrm{B} 2$ and $\mathrm{B} 2 \mathrm{~N}$ fuels were used at the same speed and maximum engine torque was achieved at $11001 / \mathrm{min}$ when B100 fuel was used as 33.136, 32.603, 32.637, 32.829, 32.700, 33.029 and $32.005 \mathrm{Nm}$, respectively.

The engine tests were performed by using ED, $\mathrm{B} 100, \mathrm{~B} 100_{\mathrm{N}}, \mathrm{B} 20, \mathrm{~B} 20_{\mathrm{N}}, \mathrm{B} 2$ and $\mathrm{B} 2{ }_{\mathrm{N}}$ fuels and the changes of the engine power, one of the engine properties, depending on the engine speed are shown in Figure 3. As a result of the engine tests, the other speed values of the fuel derived from WCOB at full load and at each round $(3100$ and $32001 / \mathrm{min}$, there were reductions of 23.346 and $35.318 \%$, respectively) and the other speed values and the values of B2 and B20 were lower than those of ED. The other speed values of the fuel derived from the NWCOB (at 3100 and 3200 1/min, 18.260 and $29.159 \%$, respectively) and the values of $\mathrm{B} 2 \mathrm{~N}$ and $\mathrm{B} 20_{\mathrm{N}}$ fuels were lower than those of ED.

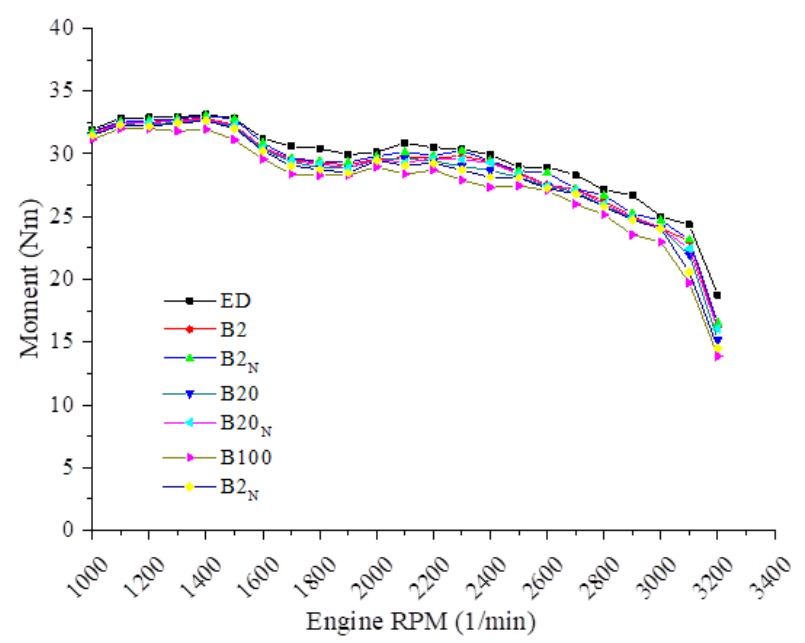

Figure 2. Change of the Torque Values of ED, Biodiesel and Fuel Blends Depending on the Engine Speed

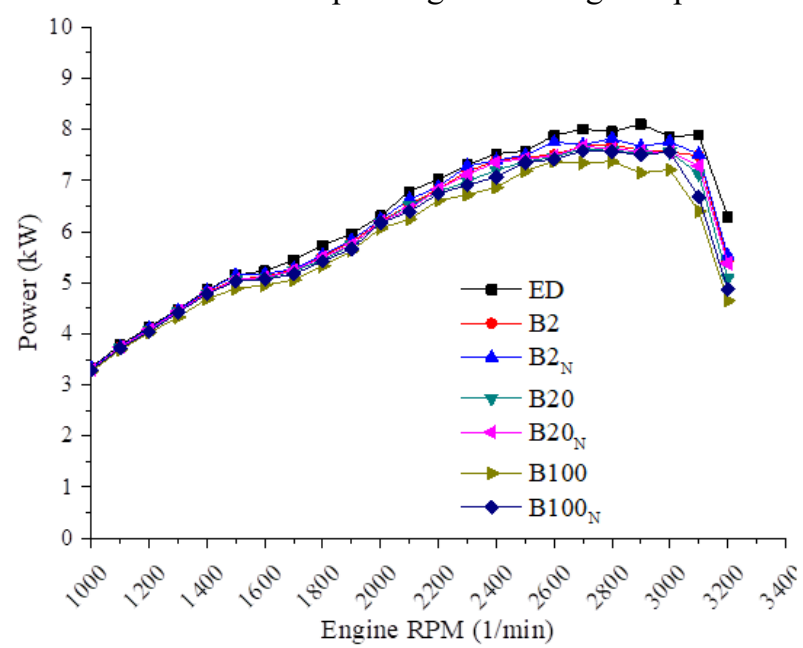

Figure 3. The Power Change Depending on the Engine Speed when Biodiesel, ED and Fuel Blends were Used The changes of specific fuel consumption, one of the engine properties, depending on the engine speed are shown in Figure 4. There was $47.11 \%$ increase in specific fuel consumption when WCOB fuel was used at maximum power (2900 1/min) in comparison to ED, and there was $52.05 \%$ increase when NWCOB fuel was used in comparison to ED. As a result of the tests 
performed by using ED, B100, B100, B20, $\mathrm{B} 20_{\mathrm{N}}, \mathrm{B} 2$ and $\mathrm{B} 2{ }_{\mathrm{N}}$ fuels, the minimum specific fuel consumption values were respectively, $183.35 \mathrm{~g} / \mathrm{kWh}$ at $10001 / \mathrm{min}, 296.61 \mathrm{~g} / \mathrm{kWh}$ at $22001 / \mathrm{min}, 317.15 \mathrm{~g} / \mathrm{kWh}$ at $23001 / \mathrm{min}$, $228.16 \mathrm{~g} / \mathrm{kWh}$ at $1000 \mathrm{1} / \mathrm{min}, 276.43 \mathrm{~g} / \mathrm{kWh}$ at $2400 \mathrm{l} / \mathrm{min}, 190.29 \mathrm{~g} / \mathrm{kWh}$ at $1000 \mathrm{1} / \mathrm{min}$ and $207.04 \mathrm{~g} / \mathrm{kWh}$ at $1000 \mathrm{1} / \mathrm{min}$.

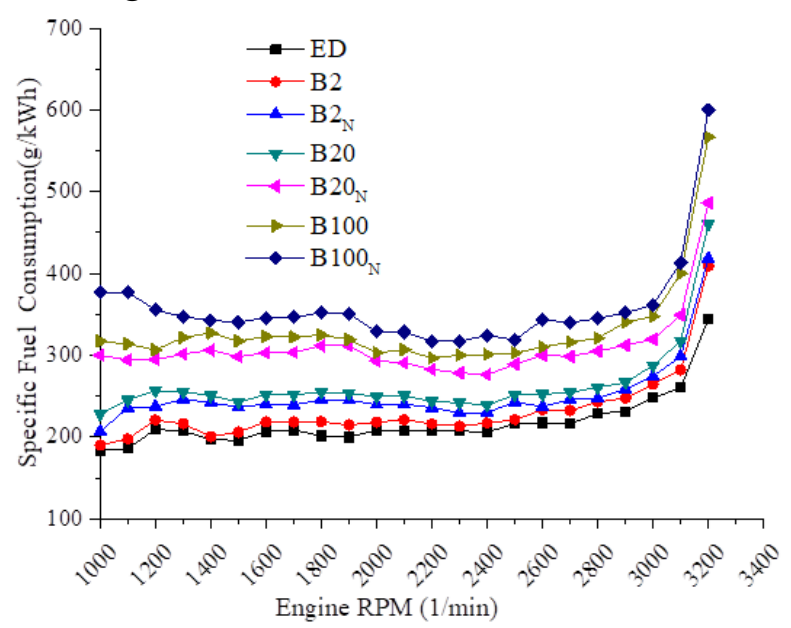

Figure 4. Specific Fuel Consumption Value Change Depending on the Engine Speed When ED, Biodiesel and Fuel Blends were Used

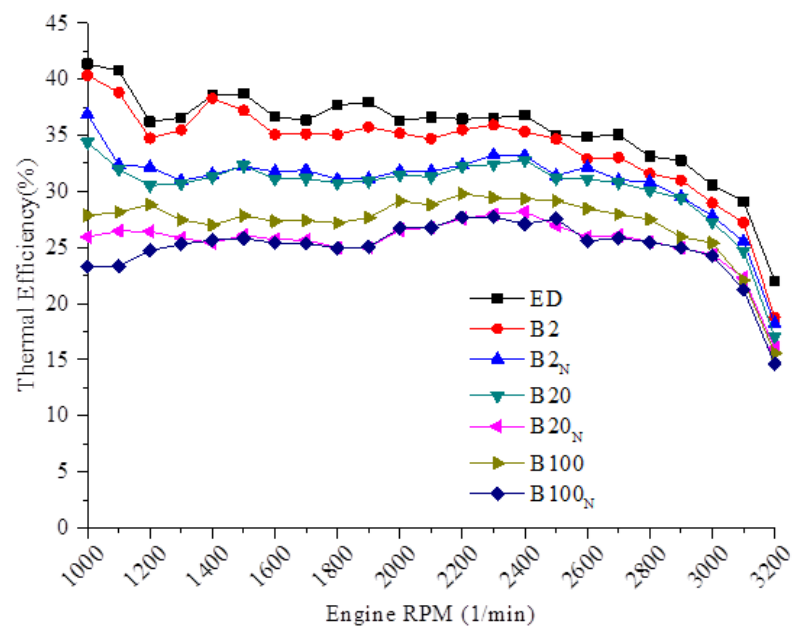

Figure 5. Thermal Efficiency Value Changes Depending on the Engine Speed of ED, Biodiesel and Fuel Blends

The efficiency of all fuels and fuel blends were lower than that of ED at each engine speed. Quite close values were received when B2 fuel was used (Figure 5). As a result of the tests performed by using ED, B2, B2 ${ }_{N}$ and B20 fuels, the highest thermal efficiency at $10001 / \mathrm{min}$ were respectively $41.37,40.35,36.88$ and $34.39 \%$; and the highest thermal efficiency at $24001 /$ min was $28.19 \%$ when $\mathrm{B} 20_{\mathrm{N}}$ fuel was used; and it was $29.79 \%$ at $22001 / \mathrm{min}$ for B100 fuel and it was $27.72 \%$ at $23001 / \mathrm{min}$ for $\mathrm{B} 100_{\mathrm{N}}$ fuel.

\subsection{Exhaust Emissions}

Exhaust gas temperature is a significant indicator used for emission parameter assessment. Maximum exhaust gas temperature values were obtained at the range of 2100 and $23001 / \mathrm{min}$. The changes of exhaust gas temperature values depending on the engine speed of ED, biodiesels and fuel blends are shown in Figure 6. Biodiesel usage usually improves $\mathrm{CO}$ emissions and increases $\mathrm{CO}_{2}$ and $\mathrm{NO}_{\mathrm{x}}$ emissions due to higher combustion temperature and extra oxygen content in the chemical composition [17].

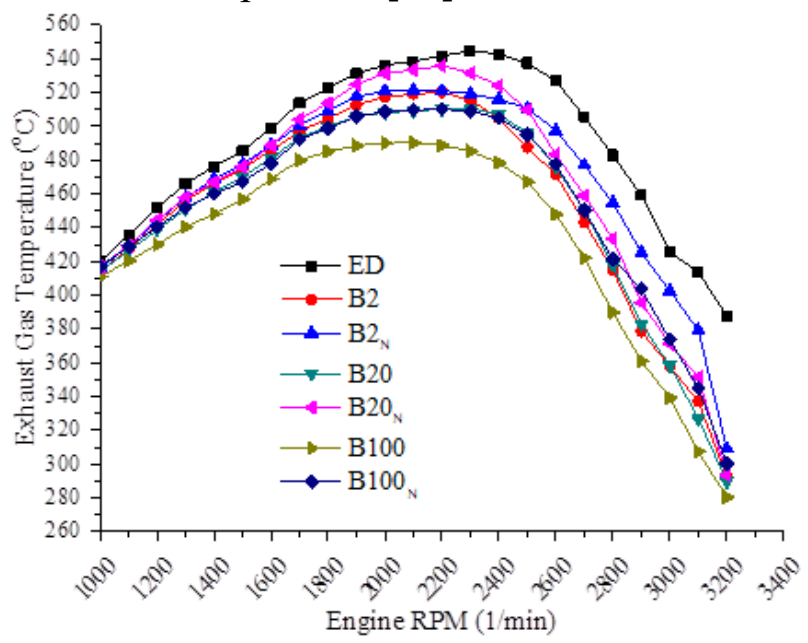

Figure 6. The Exhaust Gas Temperature Value Changes Depending of the Engine Speed of ED, Biodiesel and

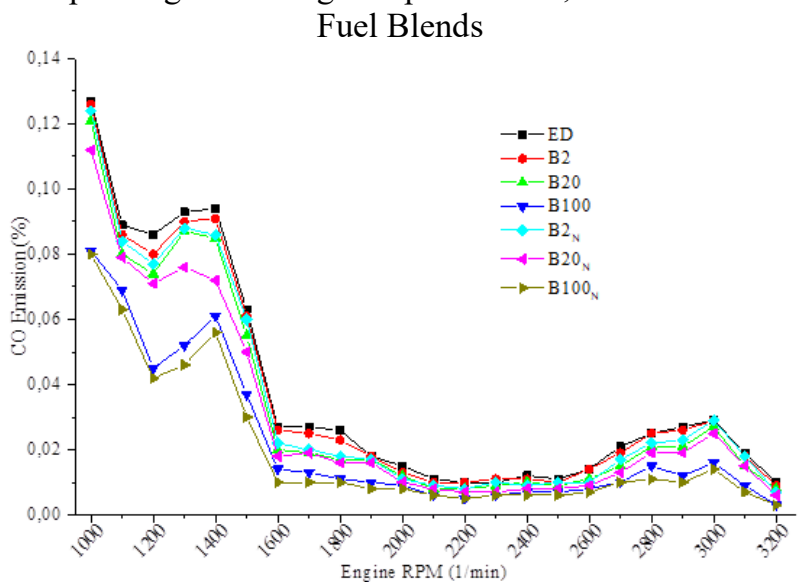

Figure7. CO Emission Change Depending on the Engine Speed

As a result of the performed tests, it was found that maximum $\mathrm{CO}$ emissions occurred at low engine speeds and $\mathrm{CO}$ emissions decreased depending on the engine speed rises (Figure 7). $\mathrm{CO}$ emissions occur mainly due to the inadequate oxygen amount in the combustion chamber. Maximum $\mathrm{CO}$ emissions of the fuels occurred at $10001 / \mathrm{min}$ and minimum CO emissions occurred at $2200 \mathrm{1} / \mathrm{min}$. 
Maximum $\mathrm{CO}_{2}$ progressed smoothly for all fuels as a result of the performed tests and it reached the maximum value at $14001 / \mathrm{min}$ of engine speed and it reached the minimum value at $2300 \mathrm{1} / \mathrm{min}$ (Figure 8 ). $\mathrm{CO}_{2}$ emission is an indicator of full burning and occurs as a result of combustion of fuels with hydrocarbon and leads to global warming with the greenhouse effect.

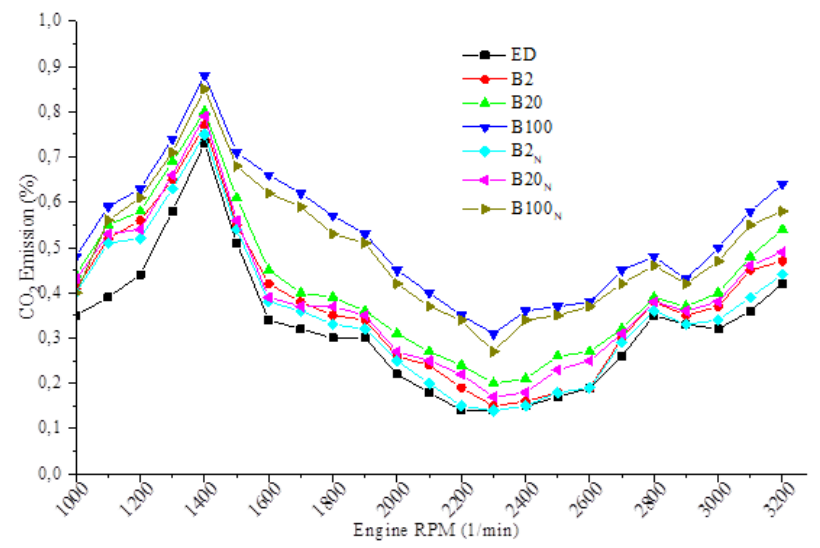

Figure 8. $\mathrm{CO}_{2}$ Emission Change Depending on the Engine Speed

As a result of the performed tests, maximum $\mathrm{HC}$ emission occurred at low engine speeds and minimum $\mathrm{HC}$ emission occurred at 1600 1/min (Figure 9). Incomplete fuel combustion, decrease of combustion temperature and insufficient oxygen amounts lead to $\mathrm{HC}$ emission.

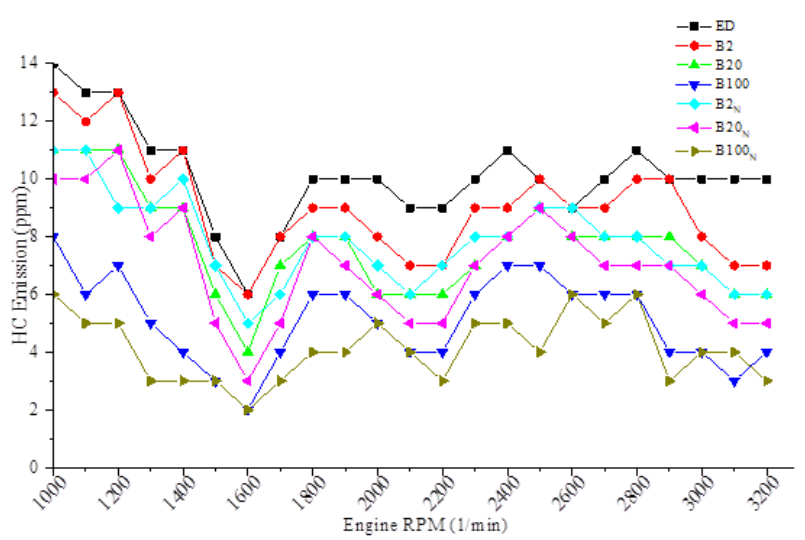

Figure 9. HC Emission Change Depending on the Engine Speed

As a result of the performed tests, maximum NO emissions occurred at $1400 \mathrm{1} / \mathrm{min}$ of engine speed (Figure 10). $\mathrm{N}$ and $\mathrm{O}$ atoms do not react under normal conditions and they react at high temperatures and lead to various nitrogen oxide compounds. These compounds are released to the atmosphere and cause acid rain. NO emission is a function of the in-cylinder gas temperature as well as the concentration of oxygen found in the fuel. Since biodiesel oxygen content is around $11-13 \%$, NO emisson rate is expected to be higher compared to ED [18].

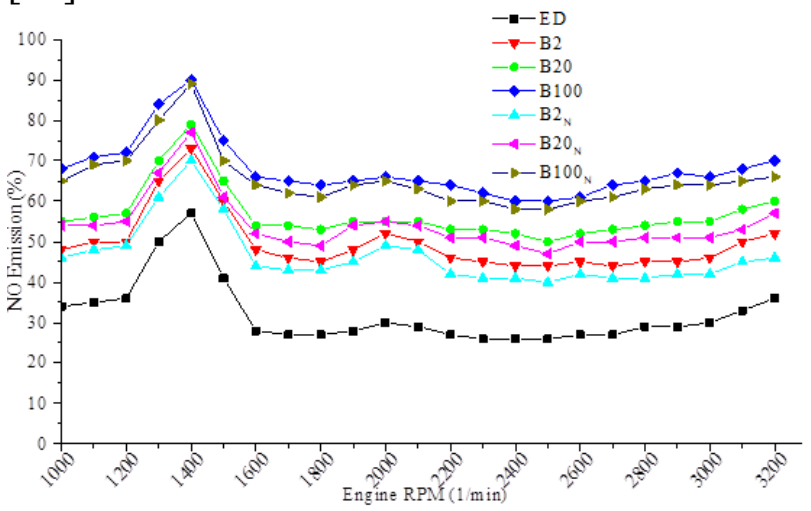

Figure 10.NO Emission Change Depending on the Engine Speed

As a result of the performed tests, maximum smoke intensity occurred at low speed values (Figure 11). Insufficient oxygen amounts during combustion leads to generation of solid carbon particles at the portion where there is excessive amount of fuel with hydrocarbons. Therefore, the amount of air taken in and the amount of oxygen contained in fuel are the most significant parameters affecting smoke intensity.

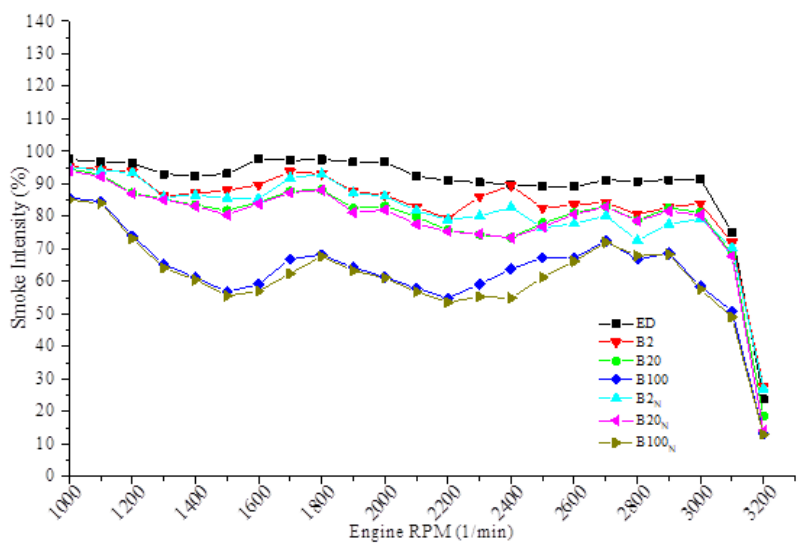

Figure 11. Smoke Intensity Change Depending on the Engine Speed

\section{Conclusion}

In conclusion, production of biodiesels by using oils that don't have nutritional value should drop biodiesel production costs substantially and contribute to the country's economy. Selection of biodiesel raw materials from among oils that are not consumed as food has the priority for sustainable biodiesel production. In this context, WCO is an appropriate raw material for Turkey. The engine power and torque values of the biodiesels and fuel blends derived from neutralize and non-neutralized WCOs were 
lower than those of ED. However, comparing their exhaust emissions, it was found that biodiesel fuels were more environmental friendly and their $\mathrm{CO}, \mathrm{HC}$ and smoke intensity emission values were lower and their $\mathrm{NO}$ and $\mathrm{CO}_{2}$ values were somewhat high.

Considering the thermal efficiency, the efficiency of ED was the highest, and when the neutralization process was applied in cooking oil, the efficiency was lower than that of the WCOB. When the neutralization process was applied in WCO, there was improvement only in exhaust emission values. This illustrated that NWCOB was more environmental friendly in comparison to WCOB.

In this study, WCO and NWCO were transformed to biodiesels and used successfully in a diesel engine with single cylinder either as in their pure form or as blends without a need for modification. WCOB and NWCOB and their blends with ED are quite appropriate for use in diesel engines in terms of their properties.

\section{Acknowledgments}

The authors would like to thank the Bozok University (Yozgat, Turkey) Coordinator of scientific research projects for their supports (2013FBE/T72).

\section{References}

1. Yaşar, B., Cost of biodiesel production in Turkey and problems. VII. National Clean Energy Symposium, UTES'2008, İstanbul, Turkey,197-204 (2008)

2. Behçet, R., Aydın, S. and Çakmak, A., Using as Fuel for a Single Cylinder Diesel Engine of Biodiesels Produced from Vegetable and Animal Waste Oils, Iğdır Univ. J. Inst. Sci. \&Tech. 2(4): 55-62 (2012)

3. Savci, S., Eryilmaz, T., Yesilyurt, M.K., The effects of biodiesel on the environment. Journal of Selcuk University Natural and Applied Science, ICOEST Special IssuePart 2:635-646(2014).

4. Şahin,S., Investigation of The Effect of Linseed Oil Biodiesel And Diesel Fuel Mixtures on Engine Performance and Exhaust. The Graduate School of Natural and Applied Science of Selçuk University the Degree of Master of Science in Agricultural Machinery, Konya, Turkey, 63pp (2013)

5. Lapuerta M, Armas O, Rodríguez-
Fernández J., "Effects of biodiesel fuels on diesel engine emissions", Prog. Energy Combust. Sci, 34:198-223 (2008)

6. Çelikten, İ., Gürü, M., Improvement of Performance and Emission Criterias of Petro diesel and Rapeseed Oil Biodiesel with Manganese Based Additive, Journal of the Faculty of Engineering and Architecture of Gazi University, 26, 3, 643-648 (2011)

7. Yilmaz, E., Solmaz, H., Polat, S., Altın M., Effect of The Three-Phase Diesel Emulsion Fuels on Engine Performance and Exhaust Emissions, Journal of the Faculty of Engineering and Architecture of Gazi University 28 (1), 127-134 (2013)

8. Chiaramonti, D.,Prussi, M., Buffi, M., Tacconi, D., "Sustainable biokerosene: Process route sand industrial demonstration activities in aviation biofuels", Applied Energy, 136, 767774 (2014)

9. Ulusoy, Y., Tekin, Y., Çetinkaya, M., Karaosmanoğlu, F., The Engine Tests of Biodiesel from Used Frying Oil, Energy Sources, 26:927-932 (2004)

10. Keskin,A., Eksi, KA., The effect of using cornoil biodiesel on performance and emissions of diesel engine, C.B.U., Journal of Science s, 49 -55 (2006)

11. Behçet, R. Aydın, S. İlkılıç, C. Aydın, H. Çakmak, A. V., Investigation of the Effect on Engine Performance and Exhaust of Emission Waste Frying Oil Methyl Ester in a Diesel Engine, The sixth International Advanced Technologies Symposium, Frrat University in Elazı ̆̆, Turkey (2011)

12. Karadirek, E., Demircan, N., Yalçındağ, S., Biodiesel and Environment, Proceedings of the Energy Plants and Green Fuels Symposium, Izmir, Turkey :159-166 (2006)

13. Yılmaz, E., Aksoy, L., Aksoy, F., Şahin, F., Uyumaz, A., "Experimental Investigation of the Effects of Biodiesel from Neutralized Waste Cooking Oil on Combustion, Performance and Emission", Electronic Journal of Machine Technologies,13(4) 53-64 (2016)

14. Eryılmaz, T., Öğ̈̈, H., Oğuz, H., Bacak, S., Investigation of The Performance and Emission Values of Non-Standard Fuels at Diesel Engines, Journal of Agricultural Machinery Science, 6(1), 45-53 (2010)

15. Eryilmaz, T., \& Yesilyurt, M. K. (2015). Comparative analysis of fuel properties of 
biodiesels derived from sunflower oil, waste sunflower oil and neutralized waste sunflower oil. Fresenius Environmental Bulletin, 24(10), 3197-3204.

16. Ery1lmaz, T., Ögüt, H. The Effect of the Different Mustard Oil Biodiesel Blending Ratios on Diesel Engines Performance. Energy Education Science and Technology Part A: Energy Science and Research 2011 Volume (Issue) 28(1): 169-180.

17. Chavan, S.B., Kumbhar, R.R., Kumar, A., and Sharma, Y.C. (2015). Study of Biodiesel Blends on Emission and Performance Characterization of a Variable Compression Ratio Engine. Energy \& Fuels, vol. 29, no. 7, pp. 4393-4398. 10.1021/acs.energyfuels.5b00742

18. Lapuerta, M.; Hernandez, J.J.; Gimenez, F. Evaluation of exhaust gas recirculation as a technique for reducing diesel engine NOx emissions. Proc. Inst. Mech. Eng. Part D J. Automob. Eng. 2000, 214, 85-93. 